\title{
Human CD4- CD8- Invariant Natural Killer T Cells Promote IgG Secretion from B Cells Stimulated by Cross-Linking of Their Antigen Receptors
}

\author{
Tomomitsu Miyasaka1 ${ }^{*}$, Yurie Watanabe1, Yukiko Akahori1 ${ }^{*}$, Namiko Miyamura1, \\ Keiko Ishii'1, Yuki Kinjo², Yoshitsugu Miyazaki², Tian-Yi Liu'3,4, Yasushi Uemura',5, \\ Kazuyoshi Kawakami1\# \\ ${ }^{1}$ Department of Medical Microbiology, Mycology and Immunology, Tohoku University Graduate School of \\ Medicine, Sendai, Japan \\ ${ }^{2}$ Department of Chemotherapy and Mycoses, National Institute of Infectious Diseases, Tokyo, Japan \\ ${ }^{3}$ Division of Immunology, Aichi Cancer Center Research Institute (ACCRI), Nagoya, Japan \\ ${ }^{4}$ Key Laboratory of Cancer Center, Chinese PLA General Hospital, Beijing, China \\ ${ }^{5}$ Division of Cancer Immunotherapy, Exploratory Oncology Research \& Clinical Trial Center, National Cancer \\ Center (NCC), Kashiwa, Japan \\ Email: "kawakami@med.tohoku.ac.jp
}

Received 30 January 2016; accepted 9 May 2016; published 12 May 2016

Copyright (C) 2016 by authors and Scientific Research Publishing Inc.

This work is licensed under the Creative Commons Attribution International License (CC BY).

http://creativecommons.org/licenses/by/4.0/

c) (i) Open Access

\begin{abstract}
Immunoglobulin (Ig) $M$ production can be induced by the interaction of thymus-independent type-2 (TI-2) antigen (Ag) with B cell Ag receptors (BCRs) without the involvement of conventional $T$ cells; for IgG production through the same process, however, a second signal is required. Previous studies have reported that invariant natural killer $T$ (iNKT) cells may be responsible for the second signal involved in IgG production. In the present study, we addressed whether human iNKT cells could participate in the production of Ig against TI-2 Ag in vitro. Two major distinct subsets of human iNKT cells, $\mathrm{CD}^{+}{ }^{+} \mathrm{CD}^{-} \beta^{-}$(CD4) and $\mathrm{CD}^{-}{ }^{-} \mathrm{CD8} \beta^{-}$[double negative (DN)] cells, were generated from peripheral blood monocytes from a healthy volunteer. BCR engagement, triggered by anti-IgM antibody stimulation, examined here as a model of BCR engagement triggered by TI-2 Ag, induced abundant IgM production by B cells. Both CD4 and DN iNKT cells reduced IgM production and conversely enhanced IgG production in a dose-dependent manner. In addition, IgG production by $\mathrm{CD}^{2}{ }^{+} \mathrm{CD}^{-} 7^{-}$(naïve) and $\mathrm{CD19}+\mathrm{CD}^{2}{ }^{+}$(memory) B cells was predominantly promoted by DN
\end{abstract}

\footnotetext{
"Present address: Tomomitsu Miyasaka, Department of Pathophysiology, Tohoku Medical and Pharmaceutical University, Sendai, Japan; Yukiko Akahori, Department of Medical Science Technology, International University of Health and Welfare, Narita, Japan. ${ }^{\#}$ Corresponding author.

How to cite this paper: Miyasaka, T., Watanabe, Y., Akahori, Y., Miyamura, N., Ishii, K., Kinjo, Y., Miyazaki, Y., Liu, T.-Y., Uemura, Y. and Kawakami, K. (2016) Human CD4 ${ }^{-} \mathrm{CD}^{-}$Invariant Natural Killer T Cells Promote IgG Secretion from B Cells Stimulated by Cross-Linking of Their Antigen Receptors. World Journal of Vaccines, 6, 34-41.

http://dx.doi.org/10.4236/wjv.2016.62005
} 
iNKT cells rather than CD4 iNKT cells; nevertheless, IgM production by both B cell subsets was similarly reduced by either subset of iNKT cells. These results suggest that the DN iNKT subsets may preferentially promote Ig class switching by B cells upon stimulation with TI-2 Ag.

\title{
Keywords
}

\author{
Invariant Natural Killer T Cells, TI-2 Antigen, B Cells, IgM, IgG
}

\section{Introduction}

The main causative bacteria of invasive infection, including Streptococcus pneumoniae and Haemophilus influenzae, possess thick polysaccharide capsules which confer the ability to resist phagocytosis by polymorphonuclear leukocytes [1]. Immunoglobulins specific for these polysaccharide capsules enhances opsonophagocytic killing (OPK) activity, which plays an important role in host protection against infections caused by these encapsulated bacteria [2] [3]. Recently, we reported that immunization with pneumococcal polysaccharide vaccine led to an increase in the serum level of serotype 3-specific IgG3, which facilitates survival after pneumococcal infection in mice [4]. Immunization with pneumococcal polysaccharide vaccine also generates polysaccharide-specific IgG response in humans [5] [6].

Polysaccharide capsule, a thymus-independent type 2 (TI-2) antigen (Ag), has highly repetitive structures with simultaneous cross-linking of B cell receptors (BCRs) and induces B cell proliferation and IgM production [7]. The antibody response induced by TI-2 Ag is smaller than that induced by thymus-dependent (TD) Ag, and consists largely of the production of low-affinity IgM by B cells without the conventionally necessary T cell involvement. In addition, however, IFN- $\gamma$ induces T cell-independent IgG production in response to TI-2 Ag [8], as this cytokine triggers the secondary stimulatory signals for $\mathrm{T}$ cell-independent $\mathrm{B}$ cell activation and isotype switching to produce IgG [9] [10].

Human invariant natural killer T (iNKT) cells express only two $\alpha \beta \mathrm{T}$ cell Ag receptors, namely, V $\alpha 24-\mathrm{J} \alpha 18$ and $\mathrm{V} \beta 11$, and have been identified as a unique lymphocyte population playing a critical role in both innate and adaptive immune responses [11] [12]. Although $\mathrm{V} \alpha 24^{+} \mathrm{V} \beta 11^{+}$iNKT cells are present only in very small proportions $(<0.01 \%-1 \%)$ in human blood [13], these cells recognize glycolipids from bacteria and/or self in context with $\mathrm{CD} 1 \mathrm{~d}$, a nonpolymorphic MHC class I-like molecule, which leads to the production of large quantities of cytokines such as IFN- $\gamma$, IL-4, IL-10 and IL-17A [14]. Human V $\alpha 24^{+}$iNKT cells comprise two distinct major subpopulations, one expressing $\mathrm{CD} 4^{+} \mathrm{CD} 8 \beta^{-}$(CD4) and the other $\mathrm{CD} 4^{-} \mathrm{CD} 8^{-}$[double negative (DN)] [13]. These two subsets of iNKT cells differ in terms of the cytokines they produce to regulate various immune responses [15]. Mice lacking iNKT cells exhibit defective IgG response to pneumococcal polysaccharide Ags, intact response to TD Ags [16] and impaired host defense against pneumococcal infection [17]. These previous observations suggest that iNKT cells may secrete the IFN- $\gamma$ that triggers isotype switching in TI-2-induced IgG production.

In the present study, we examined the in-vitro effect of human iNKT cells on Ig production by human B cells stimulated via cross-linking of their Ag receptors, which mimics BCR engagement by TI-2 Ags. We found that co-culture with iNKT cells reduced IgM production but increased IgG production by B cells stimulated via cross-linking of BCRs, and that this activity was higher in DN iNKT cells than in CD4 iNKT cells. These findings suggest that iNKT cells may contribute to the class-switching from IgM to IgG that occurs upon stimulation with TI-2 Ags.

\section{Materials and Methods}

\subsection{Ethical Statement}

All experimental protocols described in this study were reviewed and approved by the Ethics Committee for Human Experimentation at Tohoku University, Sendai, Japan (approval numbers: 2012-1-20, 2013-1-496).

\subsection{Ab and Reagents}

Alpha-galactosylceramide ( $\alpha$-GalCer; KRN7000) was purchased from Funakoshi (Tokyo, Japan). Recombinant 
human (rh) IL-2 was from PeproTech (Rocky Hill, NJ, USA). Polyclonal hIgM and hIgG were from Rockland Immunochemicals (Limerick, PA, USA). Anti-human IgM, anti-human IgG, HRP-conjugated anti-human IgM and HRP-conjugated anti-human IgG for ELISA were from Acris Antibodies (San Diego, CA, USA). Goat $\mathrm{F}\left(\mathrm{ab}^{\prime}\right) 2$ anti-hIgM and rabbit F(ab')2 anti-goat IgG for B cell stimulation were from Beckman Coulter (Fullerton, CA, USA). Anti-V $\alpha 24 \mathrm{~J} \alpha 18$ (Clone; 6B11), anti-V $\beta 11$ (C21), isotype-matched control and 7-amino-actinomycin D (7-AAD) were from BD Pharmingen (San Diego, CA, USA). Anti-CD4 (RPA-T4) and anti-CD8 (RPA-T8) were from eBioscience (San Diego, CA, USA). Memory B cell isolation kit was from Miltenyi Biotec (Bergisch Gladbach, Germany).

\subsection{Generation of V $\alpha 24 \mathrm{~J} \alpha 18^{+}$Invariant NKT Cells}

Human iNKT cells were separated from peripheral blood mononuclear cells (PBMCs) obtained from peripheral blood of healthy volunteers as described previously [18]. After 15 days of expansion, CD4 ${ }^{+}$CD8 ${ }^{-}$(CD4) and $\mathrm{CD}^{-} \mathrm{CD}^{-}$[double negative $(\mathrm{DN})$ ] iNKT subsets were sorted using a FACSAria cell sorter (Becton Dickinson, San Diego, CA, USA). The CD4 and DN iNKT cells $\left(2 \times 10^{6}\right.$ cells/well) were stimulated with irradiated allogenic PBMC $\left(1 \times 10^{7}\right.$ cells/well $)$ prepulsed for $5 \mathrm{~h}$ with $\alpha$-GalCer $(100 \mathrm{ng} / \mathrm{ml})$ in RPMI 1640 medium supplemented with $10 \%$ human serum, $100 \mathrm{U} / \mathrm{ml}$ penicillin $\mathrm{G}, 100 \mu \mathrm{g} / \mathrm{ml}$ streptomycin, $2 \mathrm{mM}$ L-glutamine, and 25 $\mathrm{mM}$ HEPES containing $20 \mathrm{U} / \mathrm{ml}$ rhIL-2. From day 3 to day 9, cells were split into two fractions once or twice daily. The cultures were expanded by adding medium containing rhIL-2. On day 11 or 12 , expanded cells were collected and used as iNKT cells. The surface phenotypes of expanded iNKT cells were identified by flow cytometry (FACSCant II; BD Biosciences). The presence of dead cells was excluded by running parallel 7-AAD-stained samples. After one or two passages of each primary cell culture, the remaining cells were used in the experiments.

\subsection{Human Peripheral Blood B Cells}

PBMCs were isolated from heparinized blood of one healthy adult volunteer by standard density gradient concentration over Ficoll-Paque PLUS (GE Healthcare Life Sciences, Piscataway, NJ, USA). Interface PBMCs were pelleted, washed twice, and resuspended in MACS buffer (Miltenyi Biotec). The naïve $\left(\mathrm{CD} 19^{+} \mathrm{CD} 27^{-}\right)$and memory phenotype $\left(\mathrm{CD} 19^{+} \mathrm{CD} 27^{+}\right) \mathrm{B}$ cells were isolated from PBMCs by a memory B cell isolation kit according to the manufacturer's protocol.

\subsection{NKT and B Cell Cultures}

The B cells used in the current assays were derived from a single donor. Initially, CD27 ${ }^{-}$and CD27 ${ }^{+}$B cells $(2.5$ $\times 10^{4}$ cells/well) were stimulated with goat $\mathrm{F}(\mathrm{ab}) 2$ anti-human $\operatorname{IgM}(1 \mu \mathrm{g} / \mathrm{ml})$ for 15 min on ice. The B cells were washed three times with culture medium, and then co-cultured with rabbit F(ab')2 anti-goat IgG ( $3 \mu \mathrm{g} / \mathrm{ml})$ in the presence or absence of CD4 or DN iNKT cells $\left(2.5 \times 10^{3}-2.5 \times 10^{4}\right.$ cells/well $)$ for five days. The culture supernatants were stored at $-80^{\circ} \mathrm{C}$ until assayed for immunoglobulins by ELISA.

\subsection{Measurement of Total IgG and IgM}

The quantities of $\operatorname{IgM}$ and $\operatorname{IgG}$ in the culture supernatants were measured by enzyme-linked immunosorbent assay (ELISA). Microtiter plates (Nunc A/S, Roskilde, Denmark) were coated with $250 \mathrm{ng} / \mathrm{ml}$ of anti-human IgM or $192 \mathrm{ng} / \mathrm{ml}$ of anti-human IgG Ab in PBS for $1 \mathrm{~h}$ at $37^{\circ} \mathrm{C}$, and blocked with $1 \% \mathrm{FCS}$ PBS at $4^{\circ} \mathrm{C}$ overnight. Prior to testing, samples were diluted with culture medium supplemented with $0.05 \%$ Tween 20 . Next, serial two-fold dilution of hIgM or hIgG to 1:1024 was performed arbitrarily; resulting solutions were added to the wells and incubated at room temperature for $2 \mathrm{~h}$. HRP-conjugated anti-human IgM or IgG antibodies diluted with 1:4000 were used as detection $\mathrm{Ab}$. The concentrations of $\operatorname{IgM}$ and $\operatorname{IgG}$ were determined based on the absorbance at $450 \mathrm{~nm}$. The detection limit was $0.2 \mathrm{ng} / \mathrm{ml}$.

\subsection{Statistical Analysis}

Data are presented as mean values \pm standard deviation (SD). Differences between the two groups were tested using two-tail analysis in an unpaired Student's $t$-test. Differences among three or more groups were tested using ANOVA with post-hoc analysis (Student-Newman-Keuls test). 


\section{Results}

\subsection{Human CD4+CD8- (CD4) and CD4-CD8- (DN) V 224 iNKT Cells}

To investigate the functional differences between the human iNKT subsets in terms of immunoglobulin production against TI-2 Ags, we initially expanded $\alpha$-GalCer-specific CD4 and DN iNKT cells separated from healthy individuals. More than $94 \%$ - 97\% of the cultured iNKT cells, including both CD4 and DN subsets, expressed an invariant TCR, consisting of $\mathrm{V} \alpha 24 \mathrm{~J} \alpha 18 \mathrm{CDR} 3$ loop and $\mathrm{V} \beta 11$. The expanded-CD4 iNKT cells were $\mathrm{CD} 4^{+} \mathrm{CD} 8^{-}$ at $98 \%-99 \%$ and $\mathrm{V} \alpha 24 \mathrm{~J} \alpha 18^{+} \mathrm{CD}^{+}$at $92 \%$. By contrast, $98 \%-99 \%$ of the DN iNKT cells were negative for expression of CD4 and CD8, whereas $97 \%$ of these cells expressed $\mathrm{V} \alpha 24 \mathrm{~J} \alpha 18$ (data not shown).

\section{2. iNKT Cell-Induced Enhancement of Immunoglobulin Production by B Cells upon Stimulation with Antigen Receptor-Engagement}

To investigate the effect of co-culture with iNKT cells on Ig production by B cells activated via cross-linking of BCRs, B cells were stimulated with anti-IgM Ab in the presence or absence of CD4 or DN iNKT cells, and the production of IgM and IgG in the culture supernatants was analyzed. As shown in Figure 1(a), B cells produced large quantities of IgM under BCR cross-linking alone, whereas the addition of CD4 iNKT cells resulted in the reduction of IgM production in a dose-dependent manner. A similar pattern was observed upon co-culture with DN iNKT cells (Figure 1(c)). By contrast, IgG production by B cells was not clearly increased when activated via BCR cross-linking alone (Figure 1(b) and Figure 1(d)). The synthesis of IgG by B cells stimulated via cross-linking of BCRs was significantly enhanced by co-culture with CD4 and DN iNKT cells in a dose- dependent manner. In addition, this activity was much higher in DN iNKT cells than in CD4 iNKT cells (Figure 1(b) and Figure 1(d)).

\subsection{Role of iNKT Cells in Immunoglobulin Production by Naïve and Memory B Cells upon Stimulation with Antigen Receptor-Engagement}

$\operatorname{IgM}^{+} \mathrm{CD} 27^{+}$memory B cells in PBMCs play an important role in anti-pneumococcal polysaccharide IgG pro-
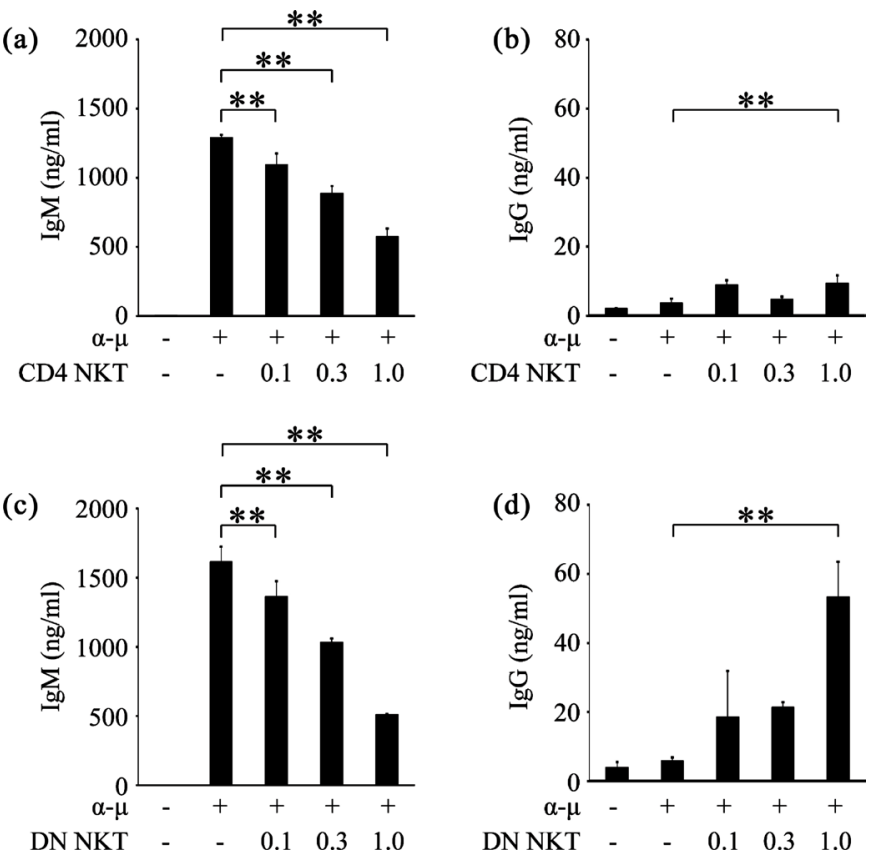

Figure 1. Effect of co-culture with iNKT cells on IgM and IgG production by B cells stimulated with anti-IgM Ab. B cells were stimulated with anti-IgM Ab in the presence or absence of CD4 iNKT cells or DN iNKT cells for five days, and the concentrations of Ig in the culture supernatants were measured. IgM (a) and IgG (b) production by B cells co-cultured with CD4 iNKT cells; IgM (c) and IgG (d) production by B cells co-cultured with DN iNKT cells. Similar results were obtained in two independent experiments. $\alpha-\mu$, anti-IgM Ab. ${ }^{* *}, \mathrm{p}<0.01$. 
duction in humans [19]. Therefore, to address the effect of co-culture with iNKT cells on Ig production by naïve $\left(\mathrm{CD} 27^{-}\right)$and memory $\left(\mathrm{CD} 27^{+}\right) \mathrm{B}$ cells, we separated B cells into two subsets according to the expression of $\mathrm{CD} 27$ and stimulated each subset with anti-IgM Ab in the presence or absence of CD4 or DN iNKT cells. As shown in Figure 2(a) and Figure 2(c), both $\mathrm{CD} 27^{+}$and $\mathrm{CD} 27^{-} \mathrm{B}$ cells produced similar levels of IgM upon BCR cross-linking, and IgM production by both subsets was significantly reduced when co-cultured with either CD4 or DN iNKT cells. The cross-linking of BCRs induced low levels of IgG production by naïve and memory $\mathrm{B}$ cells in the absence of iNKT cells, and IgG production by $\mathrm{CD} 27^{+} \mathrm{B}$ cells was significantly higher than that by $\mathrm{CD} 27^{-} \mathrm{B}$ cells. In addition, IgG production by naïve and memory B cells was significantly enhanced when they were co-cultured with either CD4 iNKT cells or DN iNKT cells; this enhancement effect was much stronger with DN iNKT cells than with CD4 iNKT cells (Figure 2(b) and Figure 2(d)).

\section{Discussion}

In the present study, we evaluated the effect of co-culture with iNKT cells on Ig production by B cells upon stimulation via crosslinking of BCRs. Our data demonstrated that CD4 iNKT cells and DN iNKT cells accelerated the isotype switching from IgM to $\operatorname{IgG}$, as shown by decreased $\operatorname{IgM}$ and increased $\mathrm{IgG}$, in both naïve and memory B cells. DN iNKT cells accelerated this response even further than CD4 iNKT cells did. These results suggest that activation of iNKT cells may serve as a potent adjuvant, eliciting TI-2 Ag-induced IgG production in the development of more effective vaccination strategies for prevention of the infectious diseases caused by encapsulated bacteria.

Kobrynski and coworkers [16] demonstrated that TI-2 Ag-specific IgG production was completely abrogated in CD1d- or $\beta 2$-microglobulin-deficient mice, suggesting that NKT cells may potentially promote IgG production in response to TI-2 Ags. In addition, we previously reported that activation of iNKT cells by $\alpha$-GalCer increased IFN- $\gamma$-producing NKT cells, and that this increase was correlated with enhanced production of the poly-
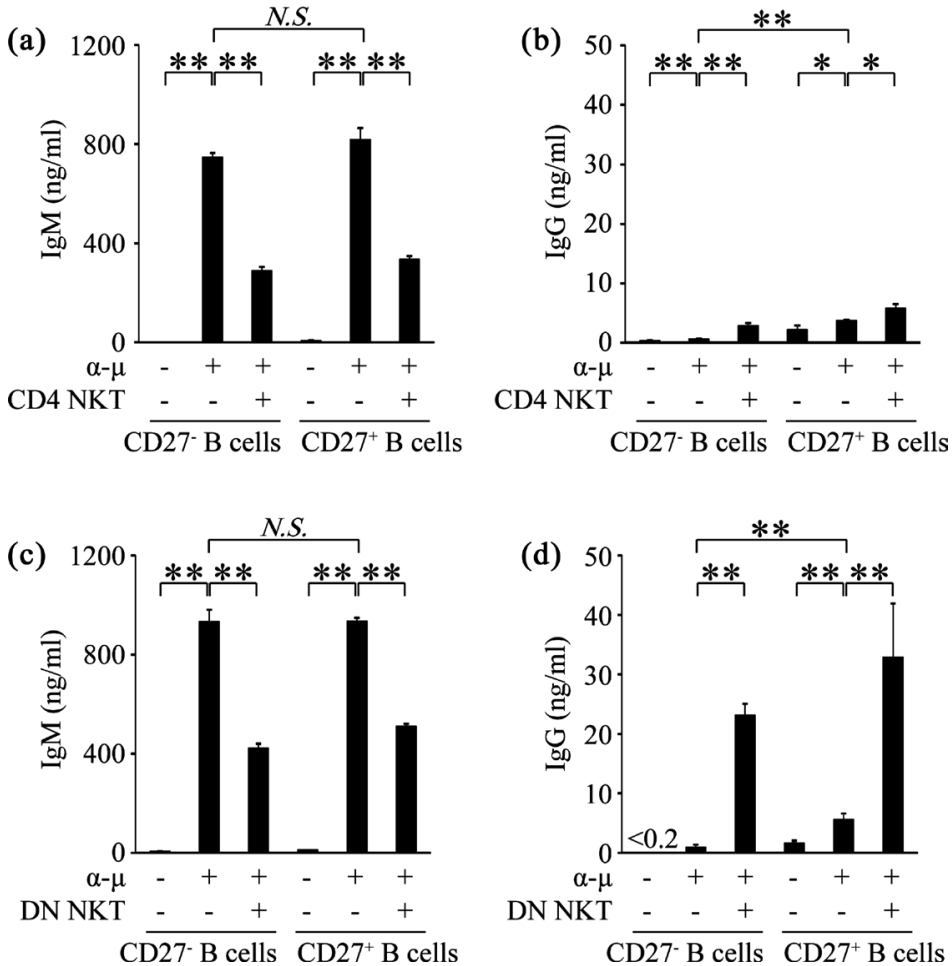

Figure 2. Effect of co-culture of iNKT cells on IgM and IgG production by naïve and memory B cells stimulated with anti-IgM Ab. CD27 $7^{+}$or $\mathrm{CD} 27^{-}$B cells were stimulated with anti-IgM Ab in the presence or absence of CD4 iNKT cells or DN iNKT cells for five days, and the concentrations of Ig in the culture supernatants were measured. IgM (a) and IgG (b) production by B cells co-cultured with CD4 iNKT cells; IgM (c) and IgG (d) production by B cells co-cultured with DN iNKT cells. Similar results were obtained in two independent experiments. $\alpha-\mu$, anti-IgM Ab. ${ }^{*}, \mathrm{p}<0.05$; ${ }^{* *}, \mathrm{p}<0.01$; NS, not significant. 
saccharide-specific IgG3 after immunization with pneumococcal polysaccharide vaccine in mice [4]. In our clinical study, immunization with anti-pneumococcal polysaccharide vaccine led to the production of serotype-specific IgG, which was correlated with an increase in DN iNKT cells in peripheral blood [5]. Thus iNKT cells are suggested to play an important role in the production of serotype-specific IgG after immunization with TI-2 Ags.

Co-culture with iNKT cells accelerated the production of IgG by B cells upon stimulation with BCR cross-linking without any exogenously added agonists of iNKT cells. In addition, $\alpha$-GalCer did not induce any further increase in IgG production promoted by iNKT cells alone (data not shown). In earlier studies by Galli et al. [20], iNKT cell-induced promotion of B cell activation was demonstrated to depend on CD1d expressed on a variety of B cell subsets and to be delivered in the absence of $\alpha$-GalCer [21]. These findings suggest that iNKT cells may recognize some endogenous ligand presented in context with CD1d on B cells, although the responsible molecule remains to be identified.

IgG production by B cells was more dramatically accelerated by DN iNKT cells than by CD4 iNKT cells. While CD4 iNKT cells have the potential to produce large amounts of Th2 cytokines such as IL-4 and IL-13, DN iNKT cells have a Th1-biased profile, enabling increased IFN- $\gamma$ production and prominent expression of NK lineage receptors [15] [22]-[24]. In addition, chemokine receptors such as CCR6 and CXCR6 are preferentially expressed on DN iNKT cells rather than CD4 iNKT cells [22] [25], though the latter are the more common type among Th1 cells [26]. CD4 co-receptor potentiates the activation of human CD4 iNKT cells by engaging CD1d molecules [24]. Previously, Galli and co-workers [20] demonstrated that, compared to DN iNKT cells, human CD4 iNKT cells induced higher levels of IgM and IgG production in $\alpha$-GalCer-pulsed B cells. In that study, B cells were considered to receive activation signals during cognate interaction with activated iNKT cells without BCR cross-linking. The current study differed from theirs in terms of the primary B cell activation method. Thus the phenotypic and functional properties of iNKT cells may be associated with IgG production by B cells stimulated with TI-2 Ags, though further investigation is required to define the molecular mechanism mediating the functional difference between CD4 iNKT cells and DN iNKT cells in T cell-independent Ig production.

TI-2 Ags are reported to generate memory B cells, although they do not elicit the Ab booster response or the germinal center formation following secondary immunization [27]. Moens and coworkers [19] reported that $\mathrm{CD} 19^{+} \mathrm{CD} 27^{+} \mathrm{IgM}^{+} \mathrm{B}$ cells were predominantly associated with an anti-polysaccharide $\operatorname{IgG}$ response after pneumococcal polysaccharide vaccination. In keeping with these previous observations, in the current study, cross-linking of BCRs induced the production of IgG by CD $27^{+}$(memory type) B cells at a higher level than that by $\mathrm{CD}_{2} 7^{-}$(naïve) B cells in the absence of iNKT cells. Yet iNKT cells promoted IgG production not only by memory B cells but also by naïve B cells. In a previous study by Bai and co-workers [28], iNKT cell activation through cognate interaction with dendritic cells induced isotype switching by B cells and promoted long-term memory response to pneumococcal capsular polysaccharides. In addition, CD4 iNKT cells and DN iNKT cells are reported to promote the proliferation of naïve and memory B cells derived from peripheral blood in vitro [20]. Thus, iNKT cells might be involved in the potentiation of IgG production by naïve and memory B cells upon stimulation with TI-2 Ags.

Maddur and coworkers demonstrated that B cells activated via BCR cross-linking enhanced the expression of OX-40L and co-stimulatory molecules such as CD80, CD86 and CD40 on DCs [29] [30]. In our previous study, DCs with increased expression of OX-40L caused NKT cells to produce substantial levels of IFN- $\gamma$ [31]. Considered collectively, B cells activated by TI-2 Ags may amplify IFN- $\gamma$ production by iNKT cells through the enhanced Th1 response induced by DCs in vivo.

\section{Conclusion}

In conclusion, we demonstrated that iNKT cells promoted the production of $\operatorname{IgG}$ by human $\mathrm{CD} 27^{+}$and $\mathrm{CD} 27^{-} \mathrm{B}$ cells upon stimulation via cross-linking of BCRs and that IgG production was more strongly promoted by DN iNKT cells than by CD4 iNKT cells. The present study provides important implications for understanding the contribution of iNKT cells to IgG production by TI-2 Ag-stimulated B cells, which is expected to be helpful in the development of more effective vaccination strategies for prevention of pneumococcal infection.

\section{Acknowledgements}

This work was supported in part by Grants from the Ministry of Health, Labour and Welfare of Japan (22- 
SHINKOU-IPPAN-014 to KK, H25-SHINKOU-WAKATE-005 to YK), a Grant from the Japan Agency for Medical Research and Development, AMED (the Research Program on Emerging and Re-emerging Infectious Diseases), and Aid Funding from the Takeda Science Foundation to YK.

\section{Conflicts of Interest}

The authors have no financial conflicts of interest.

\section{References}

[1] De Velasco, E.A., Verheul, A.F., Verhoef, J. and Snippe, H. (1995) Streptococcus pneumoniae: Virulence Factors, Pathogenesis, and Vaccines. Microbiology Reviews, 59, 591-603.

[2] Vitharsson, G., Jónsdóttir, I., Jónsson, S. and Valdimarsson, H. (1994) Opsonization and Antibodies to Apsular and Cell Wall Polysaccharides of Streptococcus pneumoniae. The Journal of Infectious Diseases, 170, 592-599. http://dx.doi.org/10.1093/infdis/170.3.592

[3] Hallström, T. and Riesbeck, K. (2010) Haemophilus influenzae and the Complement System. Trends in Microbiology, 18, 258-265. http://dx.doi.org/10.1016/j.tim.2010.03.007

[4] Miyasaka, T., Akahori, Y., Toyama, M., Miyamura, N., Ishii, K., Saijo, S., Iwakura, Y., Kinjo, Y., Miyazaki, Y., Oishi, K. and Kawakami K. (2013) Dectin-2-Dependent NKT Cell Activation and Serotype-Specific Antibody Production in Mice Immunized with Pneumococcal Polysaccharide Vaccine. PLoS One, 8, e78611. http://dx.doi.org/10.1371/journal.pone.0078611

[5] Miyasaka, T., Aoyagi, T., Uchiyama, B., Oishi, K., Nakayama, T., Kinjo, Y., Miyazaki, Y., Kunishima, H., Hirakata, Y., Kaku, M. and Kawakami, K. (2012) A Possible Relationship of Natural Killer T Cells with Humoral Immune Response to 23-Valent Pneumococcal Polysaccharide Vaccine in Clinical Settings. Vaccine, 30, 3304-3310. http://dx.doi.org/10.1016/j.vaccine.2012.03.007

[6] Grabenstein, J.D. and Manoff, S.B. (2012) Pneumococcal Polysaccharide 23-Valent Vaccine: Long-Term Persistence of Circulating Antibody and Immunogenicity and Safety after Revaccination in Adults. Vaccine, 30, 4435-4444. http://dx.doi.org/10.1016/j.vaccine.2012.04.052

[7] Mond, J.J., Lees, A. and Snapper, C.M. (1995) T Cell-Independent Antigens Type 2. Annual Review of Immunology, 13, 655-692. http://dx.doi.org/10.1146/annurev.iy.13.040195.003255

[8] Snapper, C.M., Rosas, F., Moorman, M.A., Jin, L., Shanebeck, K., Klinman, D.M., Kehry, M.R., Mond, J.J. and Maliszewski, C.R. (1996) IFN-Gamma Is a Potent Inducer of Ig Secretion by Sort-Purified Murine B Cells Activated through the mIg, but not the CD40, Signaling Pathway. International Immunology, 8, 877-885. http://dx.doi.org/10.1093/intimm/8.6.877

[9] Vos, Q., Lees, A., Wu, Z.Q., Snapper, C.M. and Mond, J.J. (2000) B-Cell Activation by T-Cell-Independent Type 2 Antigens as an Integral Part of the Humoral Immune Response to Pathogenic Microorganisms. Immunological Reviews, 176, 154-170. http://dx.doi.org/10.1034/j.1600-065X.2000.00607.x

[10] Snapper, C.M., McIntyre, T.M., Mandler, R., Pecanha, L.M., Finkelman, F.D., Lees, A. and Mond, J.J. (1992) Induction of IgG3 Secretion by Interferon Gamma: A Model for T Cell-Independent Class Switching in Response to T Cell-Independent Type 2 Antigens. The Journal of Experimental Medicine, 175, 1367-1371. http://dx.doi.org/10.1084/jem.175.5.1367

[11] Kronenberg, M. and Gapin, L. (2002) The Unconventional Lifestyle of NKT Cells. Nature Reviews Immunology, 2, $557-568$.

[12] Godfrey, D.I., MacDonald, H.R., Kronenberg, M., Smyth, M.J. and Van Kaer, L. (2004) NKT Cells: What's in a Name. Nature Reviews Immunology, 4, 231-237. http://dx.doi.org/10.1038/nri1309

[13] Rogers, P.R., Matsumoto, A., Naidenko, O., Kronenberg, M., Mikayama, T. and Kato, S. (2004) Expansion of Human Valpha24 ${ }^{+}$NKT Cells by Repeated Stimulation with KRN7000. Journal of Immunological Methods, 285, 197-214. http://dx.doi.org/10.1016/j.jim.2003.12.003

[14] Van Kaer, L., Parekh, V.V. and Wu, L. (2015) The Response of CD1d-Restricted Invariant NKT Cells to Microbial Path Ogens and Their Products. Frontiers in Immunology, 6, 226. http://dx.doi.org/10.3389/fimmu.2015.00226

[15] O’Reilly, V., Zeng, S.G., Bricard, G., Atzberger, A., Hogan, A.E., Jackson, J., Feighery, C., Porcelli, S.A. and Doherty, D.G. (2011) Distinct and Overlapping Effect or Functions of Expanded Human CD4 ${ }^{+}, \mathrm{CD} 8 \alpha^{+}$and CD4 $4^{-} \mathrm{CD} 8 \alpha^{-}$Invariant Natural Killer T Cells. PLoS One, 6, e28648. http://dx.doi.org/10.1371/journal.pone.0028648

[16] Kobrynski, L.J., Sousa, A.O., Nahmias, A.J. and Lee, F.K. (2005) Cutting Edge: Antibody Production to Pneumococcal Polysaccharides Requires CD1 Molecules and CD8 $8^{+}$T Cells. The Journal of Immunology, 174, 1787-1790. 
http://dx.doi.org/10.4049/jimmunol.174.4.1787

[17] Nakamatsu, M., Yamamoto, N., Hatta, M., Nakasone, C., Kinjo, T., Miyagi, K., Uezu, K., Nakamura, K., Nakayama, T., Taniguchi, M., Iwakura, Y., Kaku, M., Fujita, J. and Kawakami, K. (2007) Role of Interferon-Gamma in Valpha14 Natural Killer T Cell-Mediated Host Defense against Streptococcus pneumoniae Infection in Murine Lungs. Microbes and Infection, 9 364-374. http://dx.doi.org/10.1016/j.micinf.2006.12.003

[18] Liu, T.Y., Uemura, Y., Suzuki, M., Narita, Y., Hirata, S., Ohyama, H., Ishihara, O. and Matsushita, S. (2008) Distinct Subsets of Human Invariant NKT Cells Differentially Regulate T Helper Responses via Dendritic Cells. European Journal of Immunology, 38, 1012-1023. http://dx.doi.org/10.1002/eji.200737838

[19] Moens, L., Wuyts, M., Meyts, I., De Boeck, K. and Bossuyt, X. (2008) Human Memory B Lymphocyte Subsets Fulfill Distinct Roles in the Anti-Polysaccharide and Anti-Protein Immune Response. The Journal of Immunology, 181, 53065312. http://dx.doi.org/10.4049/jimmunol.181.8.5306

[20] Galli, G., Nuti, S., Tavarini, S., Galli-Stampino, L., De Lalla, C., Casorati, G., Dellabona, P. and Abrignani, S. (2003) CD1d-Restricted Help to B Cells by Human Invariant Natural Killer T Lymphocytes. The Journal of Experimental Medicine, 197, 1051-1057. http://dx.doi.org/10.1084/jem.20021616

[21] Zeng, S.G., Ghnewa, Y.G., O’Reilly, V.P., Lyons, V.G., Atzberger, A., Hogan, A.E., Exley, M.A. and Doherty, D.G. (2013) Human Invariant NKT Cell Subsets Differentially Promote Differentiation, Antibody Production, and T Cell Stimulation by B Cells in Vitro. The Journal of Immunology, 191, 1666-1676. http://dx.doi.org/10.4049/jimmunol.1202223

[22] Lee, P.T., Benlagha, K., Teyton, L. and Bendelac, A. (2002) Distinct Functional Lineages of Human Va24 Natural Killer T Cells. The Journal of Experimental Medicine, 195, 637-641. http://dx.doi.org/10.1084/jem.20011908

[23] Gumperz, J.E., Miyake, S., Yamamura, T. and Brenner, M.B. (2002) Functionally Distinct Subsets of CD1d-Restricted natural Killer T Cells Revealed by CD1d Tetramer Staining. The Journal of Experimental Medicine, 195, 625-636. http://dx.doi.org/10.1084/jem.20011786

[24] Thedrez, A., de Lalla, C., Allain, S., Zaccagnino, L., Sidobre, S., Garavaglia, C., Borsellino, G., Dellabona, P., Bonneville, M., Scotet, E. and Casorati, G. (2007) CD4 Engagement by CD1d Potentiates Activation of CD4 ${ }^{+}$Invariant NKT Cells. Blood, 110, 251-258. http://dx.doi.org/10.1182/blood-2007-01-066217

[25] Kim, C.H., Johnston, B. and Butcher, E.C. (2002) Trafficking Machinery of NKT Cells: Shared and Differential Chemokine Receptor Expression among V $\alpha 24^{+} \mathrm{V} \beta 11^{+}$NKT Cell Subsets with Distinct Cytokine-Producing Capacity. Blood, 100, 11-16. http://dx.doi.org/10.1182/blood-2001-12-0196

[26] Kim, C.H., Rott, L., Kunkel, E.J., Genovese, M.C., Andrew, D.P., Wu, L. and Butcher, E.C. (2001) Rules of Chemokine Receptor Association with T Cell Polarization in Vivo. The Journal of Clinical Investigation, 108, 1331-1339. http://dx.doi.org/10.1172/JCI13543

[27] Obukhanych, T.V. and Nussenzweig, M.C. (2006) T-Independent Type II Immune Responses Generate Memory B Cells. The Journal of Experimental Medicine, 203, 305-310. http://dx.doi.org/10.1084/jem.20052036

[28] Bai, L., Deng, S., Reboulet, R., Mathew, R., Teyton, L., Savage, P.B. and Bendelac, A. (2013) Natural Killer T (NKT)-B-Cell Interactions Promote Prolonged Antibody Responses and Long-Term Memory to Pneumococcal Capsular Polysaccharides. Proceedings of the National Academy of Sciences of the United States of America, 110, 1609716102. http://dx.doi.org/10.1073/pnas.1303218110

[29] Maddur, M.S. and Bayry, J. (2015) B Cells Drive Th2 Responses by Instructing Human Dendritic Cell Maturation. OncoImmunology, 4, e1005508. http://dx.doi.org/10.1080/2162402x.2015.1005508

[30] Maddur, M.S., Sharma, M., Hegde, P., Stephen-Victor, E., Pulendran, B., Kaveri, S.V. and Bayry, J. (2014) Human B Cells Induce Dendritic Cell Maturation and Favour Th2 Polarization by Inducing OX-40 Ligand. Nature Communications, 9, No. 4092. http://dx.doi.org/10.1038/ncomms5092

[31] Zaini, J., Andarini, S., Tahara, M., Saijo, Y., Ishii, N., Kawakami, K., Taniguchi, M., Sugamura, K., Nukiwa, T. and Kikuchi, T. (2007) OX40 Ligand Expressed by DCs Costimulates NKT and CD4 ${ }^{+}$Th Cell Antitumor Immunity in Mice. The Journal of Clinical Investigation, 117, 3330-3338. http://dx.doi.org/10.1172/JCI32693 